DOI 10.22460/jpmi.v1i3.445-452

\title{
PENGARUH PEMBELAJARAN BERBASIS MASALAH TERHADAP KEMAMPUAN PEMECAHAN MASALAH MATEMATIS SISWA SMP
}

\author{
Asfi Yuhani ${ }^{1}$, Luvy Sylviana Zanthy ${ }^{2}$, Heris Hendriana ${ }^{3}$ \\ ${ }^{1,2,3}$ IKIP Siliwangi Bandung, Jl. Terusan Jenderal Sudirman, Cimahi, Jawa Barat, Indonesia \\ ${ }^{1}$ asfiyuhani21@gmail.com, ${ }^{2}$ Lszanthy@gmail.com, ${ }^{3}$ herishen@ stkipsiliwangi.ac.id
}

Diterima: 20 April 2018; Disetujui: 28 Mei 2018

\begin{abstract}
Problem-solving ability is the ability to solve non-routine problems related to everyday life. Problemsolving learning more focuses on processes and strategies. So the process skills and strategies for solving a problem become the essential capability that must be owned in mathematics learning. The purpose of this study is to know the effect of problem-based learning approach to the problem-solving ability of junior high school students. The research method used in this research is the experimental method. The population taken in this research is all of VII grade student SMP Negeri 2 Cimahi. As a sample, the researcher took a random class, where grade VII-1 with the number of 34 students was used as the experimental class and class VII-2 with the total of 34 students used as control class. The instrument used in this research that is in the form of problem description of problem-solving ability mathematics consists of 5 item. The results of this study indicate that the problem-solving ability of the mathematical group of students whose learning using problem-based learning approaches better than the group of students whose learning using ordinary learning.
\end{abstract}

Keywords: Mathematical Problem Solving, Problem Based Learning

\begin{abstract}
Abstrak
Kemampuan pemecahan masalah adalah kemampuan menyelesaikan permasalahan non-rutin yang berhubungan dengan kehidupan sehari-hari. Pembelajaran pemecahan masalah lebih berfokus pada proses dan strategi. Sehingga keterampilan proses dan strategi dalam memecahkan suatu permasalahan tersebut menjadi kemampuan pokok yang wajib dimiliki dalam belajar matematika. Tujuan melakukan penelitian ini ialah untuk mengetahui pengaruh pendekatan pembelajaran berbasis masalah terhadap kemampuan pemecahan masalah matematis siswa SMP. Metode penelitian yang digunakan dalam penelitian ini yaitu metode eksperimen. Populasi yang diambil dalam penelitian ini adalah seluruh siswa kelas VII SMP Negeri 2 Cimahi. Sebagai sampel peneliti mengambil secara acak kelas, dimana kelas VII-1 dengan jumlah 34 siswa digunakan sebagai kelas eksperimen dan kelas VII-2 dengan jumlah 34 siswa digunakan sebagai kelas kontrol. Instrumen yang dipakai di dalam penelitian ini yaitu berupa soal uraian kemampuan pemecahan masalah matematis yang terdiri dari 5 buah soal. Hasil dari penelitian ini menunjukkan bahwa kemampuan pemecahan masalah matematis kelompok siswa yang pembelajarannya menggunakan pendekatan pembelajaran berbasis masalah lebih baik dari kelompok siswa yang pembelajarannya menggunakan pembelajaran biasa.
\end{abstract}

Kata Kunci: Pemecahan Masalah Matematis, Pembelajaran Berbasis Masalah

How to cite: Yuhani, A., Zanthy, L. S., \& Hendriana, H. (2018). Pengaruh Pembelajaran Berbasis Masalah terhadap Kemampuan Pemecahan Masalah Matematis Siswa SMP. JPMI Jurnal Pembelajaran Matematika Inovatif, 1 (3), 445-452. 


\section{PENDAHULUAN}

Kurikulum di Indonesia memiliki tujuan yang harus dicapai melalui pembelajaran matematika. Menurut KTSP (2006), salah satu tujuan yang diharapkan dapat dicapai melalui pembelajaran matematika adalah memecahkan masalah yang mencakup kemampuan memahami masalah, merancang model matematika dan menyelesaikannya, serta menafsirkan solusi yang telah diperoleh (Hendriana, H., \& Sumarmo, 2014).

Selain itu National Council of Teachers of Mathematics (NCTM) (Nurlaelasari, 2016) menyatakan bahwa standar utama yang ada dalam pembelajaran matematika antara lain kemampuan komunikasi, pemecahan masalah, kemampuan penalaran, kemampuan koneksi serta kemampuan representasi. Selanjutnya Zanthy (2016) mengungkapkan bahwa kemampuan seseorang agar dapat berhasil dalam kehidupannya antara lain ditentukan oleh keterampilan berpikirnya, terutama dalam upaya memecahkan masalah-masalah dalam kehidupan yang dihadapi.

Melihat dari uraian tersebut, KPM termasuk salah satu tujuan dalam pembelajaran matematika yang harus dicapai. Karena pada dasarnya dalam belajar matematika tidak terlepas dari masalah. Kemampuan pemecahan masalah merupakan kemampuan menyelesaikan permasalahan non-rutin yang biasanya berhubungan dengan masalah dalam kehidupan nyata, dalam pembelajarannya pemecahan masalah lebih menekankan pada proses dan strategi. Oleh karena itu keterampilan proses maupun strategi dalam memecahkan permasalahan tersebut menjadi kemampuan dasar di dalam belajar matematika (Hidayat \& Sariningsih, 2018; Wahyu, 2014).

Pemecahan masalah perlu pengetahuan, kemampuan, kesiapan, kreativitas, serta penerapannya dalam menyelesaikan masalah nyata yang dihadapi siswa sehingga dapat membantu menyelesaikan suatu persoalan. Karena kepentingan serta kegunaannya tersebut maka kemampuan pemecahan masalah yang selanjutnya disebut KPM perlu diajarkan kepada siswa.

Kenyataan di lapangan KPM siswa masih rendah, menurut PISA (Pradhini, 2016), kemampuan pemecahan masalah di Indonesia hingga sekarang masih sangat rendah yakni dari 100 siswa, 73 diantaranya berada di level 1 yang berarti sebagian besar siswa masih belum mencapai level 1 yang merupakan level paling rendah. Berdasarkan masalah tersebut maka diperlukan solusi dan inovasi dalam pembelajaran matematika, baik strategi, metode, model, maupun pendekatan pembelajaran yang sesuai yang hasilnya mampu meningkatkan KPM matematis siswa. Salah satu inovasi yang ada dalam suatu pembelajaran matematika yaitu dengan pembelajaran berbasis masalah.

Menurut Marsigit (Muliawati, 2015), ciri-ciri pembelajaran berbasis masalah yakni terdapat permasalahan nyata yang digunakan untuk belajar berpikir kritis, keterampilan untuk mampu memecahkan suatu masalah dan memperoleh pengetahuan. Pembelajaran diawali dengan pendapat bahwa suatu pembelajaran pada dasarnya adalah sebuah proses yang aktif, kolaboratif, terintegrasi, serta konstruktif dan dipengaruhi oleh faktor-faktor sosial serta kontekstual. Pembelajaran lebih terpusat pada siswa, guru hanya menyediakan fasilitas, dan soal-soal terbuka atau kurang terstruktur yang digunakan sebagai rancangan awal untuk belajar.

Hal ini menunjukkan pendekatan ini memungkinkan untuk dapat meningkatkan KPM siswa. Berdasarkan paparan di atas, penulis berminat melakukan penelitian yang terfokus pada 
pedekatan berbasis masalah untuk mengetahui pengaruhnya dalam upaya peningkatan KPM matematis siswa.

\section{Kemampuan pemecahan Masalah}

Pemecahan masalah yaitu sebuah cara yang dilakukan dalam pendidikan dan pengajaran untuk mencapai tujuan pelajaran tersebut dengan cara membiasakan peserta didik agar dapat menentukan penyelesaian suatu permasalahan, mulai dari masalah yang paling mudah hingga yang paling sulit dikerjakan sendiri.

KPM merupakan kemampuan menyelesaikan permasalahan non-rutin yang saling berelasi dengan kehidupan nyata. Pembelajaran pemecahan masalah lebih terfokus pada proses dan strategi. Oleh karena itu keterampilan proses maupun strategi dalam memecahkan permasalahan tersebut menjadi kemampuan dasar di dalam belajar matematika. Dalam memecahkan masalah perlu pengetahuan, kemampuan, kesiapan, kreativitas, serta penerapannya di dalam menyelesaikan masalah-masalah kehidupan sehari-hari.

Ruseffendi (Nurlaelasari, 2016) mengungkapkan bahwa seseorang yang menganggap suatu soal sebagai soal pemecahan masalah apabila seseorang tersebut memiliki kemampuan dan pengetahuan untuk menyelesaikannya, namun pada saat dirinya memperoleh soal pemecahan masalah tersebut ia belum mengetahui solusi dalam menyelesaikannya. Dalam prosesnya siswa membutuhkan kesiapan, kemauan dan pengetahuan-pengetahuan baru sehingga dapat menyelesaikan soal-soal yang diberikan.

Selanjutnya menurut Sumarmo (2013), KPM sebagai kemampuan yang wajib dicapai terangkum dalam indikator-indikator pemecahan masalah sebagai berikut:

1. Mengidentifikasi adanya kecukupan data

2. Membuat model matematik dari suatu situasi atau masalah sehari-hari dan menyelesaikannya

3. Memilih dan menerapkan strategi untuk penyelesaian masalah matematika dan atau di luar matematika

4. Menjelaskan atau menginterpretasikan hasil sesuai dengan permasalahan asal, serta memeriksa kebenaran hasil atau jawaban.

5. Menggunakan matematika secara bermakna.

\section{Pembelajaran berbasis masalah}

Pembelajaran berbasis masalah untuk selanjutnya disingkat menjadi PBM merupakan suatu pendekatan yang pembelajarannya diawali dengan memberikan permasalahan selanjutnya siswa diminta menyelesaikan permasalahan tersebut, namun untuk dapat menyelesaikan permasalahan itu siswa membutuhkan pengetahuan-pengetahuan yang baru. Sehingga akhirnya peserta didik mampu menemukan secara mandiri suatu konsep dalam matematika. Dalam pembelajarannya, siswa diharapkan membentuk suatu pengetahuan baru berdasarkan pengetahuan yang suda dimiliki dengan dibimbing dan diarahkan guru.

Sumarmo (Yuniarti, 2016) mengatakan PBM merupakan suatu pendekatan pembelajaran, yang digunakan untuk menemukan kembali (reinvention) dan memahami materi, konsep, prinsip matematika. Pembelajaran dimulai dengan penyajian suatu situasi ataupun masalah nyata selanjutnya secara induksi siswa dapat menemukan sendiri konsep/prinsip matematika. 
Langkah-langkah PBM menurut Kemendikbud adalah: 1) Orientasi siswa pada masalah. 2) Mengorganisasikan siswa untuk belajar. 3) Membimbing dalam penyelidikan individu dan kelompok. 4) Mengembangkan dan menyajikan hasil karya. 5) Menganalisis dan memberi penilaian terhadap proses pemecahan masalah (Setiawati, 2014).

\section{METODE}

Populasi yang dipakai dalam penelitian ini mencakup seluruh siswa kelas VII SMP Negeri 2 Cimahi, sedangkan pengambilan sampel dilakukan secara acak dua kelas. Metode penelitian yang diterapkan pada penelitian ini merupakan metode eksperimen sehingga pelaksanaannya menggunakan dua kelompok kelas sebagai kelas eksperimen (kelas VII-1) dan kelas kontrol (kelas VII-2), dimana kelas eksperimen dilaksanakan suatu pembelajaran yang menggunakan pendekatan PBM, sedangkan kelas kontrol dilaksanakan pembelajaran yang biasanya diterapkan di sekolah. Sebelum dan setelah dilaksanakan pembelajaran diberikan tes awal (pretes) serta tes akhir (postes). Sehingga untuk desain penelitiannya yaitu sebagai berikut:

$$
\begin{array}{llll}
\mathrm{A} & 0 & \mathrm{x} & 0 \\
\mathrm{~A} & 0 & & 0
\end{array}
$$

(Ruseffendi, 2010)

Keterangan:

A : Penentuan sampel secara acak kelas

$0 \quad$ : Pretes/Postes

$\mathrm{X} \quad$ : Pembelajaran dengan pendekatan berbasis masalah.

\section{HASIL DAN PEMBAHASAN}

\section{Hasil}

Data dalam penelitian ini diperoleh dari skor tes awal (pretes) dan skor tes akhir (postes) dari instrumen tes berupa soal uraian yang terdiri dari lima soal menggunakan materi yang sudah dipelajari. Sebelum digunakan, soal tersebut terlebih dahulu di uji cobakan guna mengetahui tingkat validitas dan reliabilitas dari tiap butir soal.

Hasil dari nilai tes awal dan akhir kemudian diolah secara kuantitatif dengan menggunakan Software SPSS 22 untuk selanjutnya dianalisis. Data pretes digunakan untuk dapat mengetahui kemampuan awal siswa, data postes digunakan untuk dapat mengetahui kemampuan siswa setelah diberikan perlakuan, sedangkan untuk mengetahui pengaruh pendekatan PBM terhadap KPM matematis siswa maka dilakukan perhitungan N-Gain (gain ternormalisasi) yang diperoleh dari selisih skor pretes dan skor postes dibagi selisih skor maksimal ideal dan skor pretes yang dikembangkan (Zarkasyi, Lestari, \& Yudhanegara, 2015) sebagai berikut:

$$
\text { Gain ternormalisasi }(\mathrm{N}-\text { Gain })=\frac{\text { Skor Postes-Skor Pretes }}{\text { Skor Maksimal Ideal-Skor Pretes }}
$$

Nilai N-Gain berkisar antara nilai 0 sampai dengan 1 . Tinggi atau rendahnya nilai $\mathrm{N}-$ Gain ditentukan berdasarkan kriteria berikut: 
Tabel 1. Kriteria Skor Gain Ternormalisasi (N-Gain)

\begin{tabular}{cc}
\hline Skor $\mathbf{N}$-Gain & Interpretasi \\
\hline $\mathrm{G} \geq 0,7$ & Tinggi \\
$0,3 \leq \mathrm{g}<0,7$ & Sedang \\
$\mathrm{g}<0,3$ & Rendah \\
\hline
\end{tabular}

(Zarkasyi, Lestari, \& Yudhanegara, 2015)

Selanjutnya, data N-Gain harus di uji. Dimana pengujiannya adalah sebagai berikut: (1) Uji normalitas data hasil N-Gain dengan uji Kolmogorov Smirnov dengan taraf signifikansi 0,05 untuk mengetahui apakah data berdistribusi normal ataukah tidak. (2) Uji homogenitas varians dengan menggunakan uji Levene's test dan taraf signifikansi 0,05. (3) Uji signifikansi perbedaan dua rata-rata yang dilakukan dengan menggunakan uji-t untuk mengetahui apakah kedua kelas memiliki hasil belajar yang setara atau berbeda.

KPM matematis siswa diperoleh berdasarkan skor hasil pretes dan postes, kemudian dihitung skor gain ternormalisasi (N-Gain) dari hasil tes kelas eksperimen dan kontrol. Data hasil skor pretes, skor postes, dan skor N-Gain KPM secara ringkas disajikan dalam tabel berikut:

Tabel 2. Rekapitulasi Hasil Pretes, Postes, dan Gain Ternormalisasi (N-Gain) KPM Matematis

\begin{tabular}{lccccccc}
\hline \multirow{2}{*}{ Kelas } & Jumlah & \multicolumn{3}{c}{ Rata-rata } & \multicolumn{3}{c}{ Standar Deviasi } \\
\cline { 3 - 8 } & Siswa & Pretes & Postes & N-Gain & Pretes & Postes & N-Gain \\
\hline Eksperimen & 34 & 9,24 & 42,91 & 0,52 & 5,03 & 11,59 & 0,15 \\
Kontrol & 34 & 11,53 & 37,62 & 0,42 & 4,26 & 12,25 & 0,17 \\
\hline
\end{tabular}

Hasil pengujian menunjukkan terdapat peningkatan KPM ditinjau dari hasil rata-rata skor pretes dan postes, dimana kelas eksperimen yang menggunakan PBM lebih baik dari kelas kontrol yang menerapkan pembelajaran biasa. Pada kelas eksperimen rata-rata skor pretes = 9,24 kemudian meningkat saat postes sebesar 33,67 yakni menjadi 42,91, sedangkan pada kelas kontrol dari rata-rata skor pretes $=11,53$ pada saat postes hanya meningkat sebesar 26,09 menjadi 37,62. Sementara untuk nilai rata-rata skor $\mathrm{N}-$ Gain pada kelas eksperimen $=$ 0,52 dan kontrol $=0,42$.

Untuk mengetahui peningkatan KPM matematis antara kelompok siswa yang mendapatkan pembelajaran dengan menggunakan PBM dan kelompok siswa yang menerima pembelajaran biasa maka dilakukan analisis terhadap kelompok data N-Gain. Rata-rata gain pada kelas eksperimen serta kelas kontrol secara ringkas disajikan ke dalam tabel berikut:

Tabel 3. Rekapitulasi Rata-rata, Kualifikasi, dan Standar Deviasi N-Gain KPM Matematis

\begin{tabular}{llll}
\hline Kelas & Mean & Kualifikasi & Std. Deviasi \\
\hline Eksperimen & 0,52 & Sedang & 0,15 \\
Kontrol & 0,42 & Sedang & 0,17 \\
\hline
\end{tabular}


Berdasarkan tabel 3 tersebut dapat dilihat bahwa hasil rata-rata kelas eksperimen $=0,52$ lebih besar dari kelas kontrol yang rata-ratanya 0,42 . Berdasarkan kriteria skor N-Gain, rata-rata nilai kelas eksperimen maupun kontrol keduanya berada di rentang $0,3 \leq \mathrm{g}<0,7$ sehingga kedua kelas peningkatannya termasuk kategori sedang. Selanjutnya, untuk dapat mengetahui apakah data berdistribusi normal atau tidak, maka dilakukan uji normalitas dengan uji Kolmogorov Smirnov yang secara ringkas disajikan dalam tabel berikut:

Tabel 4. Uji Normalitas N-Gain KPM Matematis

\begin{tabular}{lccc}
\hline \multirow{2}{*}{ Kelas } & \multicolumn{3}{c}{ Kolmogorov-Smirnov $^{\text {a }}$} \\
\cline { 2 - 4 } & Statistic & Df & Sig. \\
\hline Eksperimen & 0,14 & 34 & 0,09 \\
Kontrol & 0,13 & 34 & 0,14 \\
\hline
\end{tabular}

Berdasarkan data pada tabel 4 dapat diketahui bahwa gain untuk setiap kelas berdistribusi normal. Karena data berdistribusi normal untuk selanjutnya dapat dilakukan uji homogenitas varians data dengan uji Levene's Test, berikut hasil uji homogenitas N-Gain:

Tabel 5. Uji Homogenitas N-Gain KPM Matematis

\begin{tabular}{llcccc}
\hline & & $\begin{array}{c}\text { Levene } \\
\text { Statistic }\end{array}$ & df1 & df2 & Sig. \\
\hline Gain & Based on Mean & 0,05 & 1 & 66 & 0,83 \\
& Based on Median & 0,09 & 1 & 66 & 0,77 \\
Based on Median and with adjusted df & 0,09 & 1 & 64,74 & 0,77 \\
Based on trimmed mean & 0,05 & 1 & 66 & 0,83 \\
\hline
\end{tabular}

Dari tabel 5 menunjukkan bahwa nilai sig. $=0,83$ lebih besar dari $\alpha=0,05$ sehingga Ho diterima atau dapat disimpulkan bahwasannya tidak terdapat perbedaan varians dari setiap kelas.

Selanjutnya untuk mengetahui apakah ada ataukah tidak perbedaan rata-rata kemampuan pemecahan masalah di kedua kelas. Hasil uji-t secara ringkas disajikan dalam tebel berikut:

Tabel 6. Uji Perbedaan Dua Rata-Rata N-Gain KPM Matematis

\begin{tabular}{|c|c|c|c|c|}
\hline \multicolumn{3}{|c|}{ t-test for Equality of Means } & Kesimpulan & Keterangan \\
\hline $\mathbf{t}$ & df & Sig. (2-tailed) & \multirow{2}{*}{ Ho ditolak } & \multirow{2}{*}{$\begin{array}{l}\text { Berbeda } \\
\text { signifikan }\end{array}$} \\
\hline 2,63 & 66 & 0,01 & & \\
\hline
\end{tabular}

Pada Tabel tersebut diperoleh hasil uji-t nilai sig. (2-tailed) data N-Gain adalah 0,01. Pada data postes dan $\mathrm{N}$-gain digunakan sig. (1-tailed) sehingga nilai sig. nya menjadi 0,005 hal ini berarti nilai sig. kurang dari $\alpha=0,05$ maka Ho ditolak artinya berbeda signifikan. Sehingga dapat dibuat kesimpulan bahwa peningkatan KPM matematis kelompok siswa yang menerima perlakuan pembelajaran dengan menggunakan pendekatan PBM lebih baik dibanding siswa yang menerima perlakuan dengan pembelajaran biasa. 


\section{Pembahasan}

Berdasarkan hasil analisis data statistik yang telah dilakukan diketahui bahwa KPM matematis siswa yang mmenerima perlakuan pembelajaran dengan menggunakan pendekatan PBM lebih baik dibanding siswa yang memperoleh pembelajaran biasa. Hal ini senada dengan hasil penelitian yang telah dilaksanakan Sari, Elniati, \& Fauzan (2014) yang menyatakan bahwa peningkatan KPM matematis siswa yang diajar dengan pendekatan PBM lebih tinggi daripada siswa yang diajar secara konvensional.

Hal ini terjadi dikarenakan pada kelas eksperimen yang menggunakan PBM, siswa ditekankan untuk dapat lebih aktif dan terbiasa mendapatkan permasalahan-permasalahan, pada awal pembelajaran siswa diberikan masalah yang sesuai dengan kehidupan nyata untuk diselesaikan oleh siswa, sehingga siswa dapat mengembangkan keterampilannya dalam memecahkan permasalahan serta mendapatkan pengetahuan yang baru.

Setelah diberikan masalah, guru membimbing siswa untuk belajar dimana siswa terlebih dahulu duduk bersama kelompoknya sesuai arahan guru kemudian menyelesaikan permasalahan yang terdapat di LAS yang diberikan guru dengan cara diskusi kelompok. Dalam proses penyelesaian masalah siswa membaca buku siswa maupun sumber lain untuk memperoleh informasi yang berkenaan dengan masalah yang diberikan. Dengan bimbingan guru siswa mencari penyelesaian mengenai masalah yang diberikan yaitu dengan diskusi bersama kelompok.

Tahap yang dilakukan selanjutnya ialah guru meminta salah satu kelompok untuk mengembangkan hasil diskusi kelompoknya dan menyajikannya di depan kelas. Kelompok penyaji dipilih berdasarkan diskusi siswa. Setelah ditentukan satu kelompok yang akan menjadi kelompok penyaji, selanjutnya kelompok penyaji presentasi di depan kelas sementara kelompok lainnya memberi tanggapan terhadap hasil diskusi yang disampaikan kelompok penyaji sehingga pada tahap ini siswa terlatih menjadi lebih aktif.

Kesulitan yang dihadapi adalah siswa belum terbiasa memperoleh masalah yang berkenaan dengan kehidupan sehari-hari untuk melatihnya, guru bersama siswa menganalisa proses pemecahan masalah yang telah diperoleh, untuk mengevaluasi kemampuan memecahkan masalah siswa pada tiap pertemuan guru memberikan soal evaluasi berkaitan dengan materi yang diperlajari, sehingga siswa terbiasa menyelesaikan permasalahan yang berkenaan dengan kehidupan sehari-hari.

Dengan menggunakan pendekatan PBM siswa menjadi terbiasa aktif dengan diskusi kelompok dan menyelesaikan permasalahan-permasalahan yang berkorelasi dengan kehidupan sehari-hari secara sistematis sehingga pembelajaran dengan pendekatan ini dapat mempengaruhi peningkatan KPM siswa pada materi yang dipelajari sesuai dengan indikator.

\section{KESIMPULAN}

Berdasarkan hasil penelitian dan menganalisa data terkait kemampuan pemecahan masalah maka didapat kesimpulan KPM matematis siswa yang dalam pembelajarannya menggunakan pendekatan PBM lebih baik dibanding kelompok siswa yang dalam pelaksanaannya memperoleh pembelajaran biasa. Hal ini dapat diketahui dari data rata-rata hasil uji $\mathrm{N}$-gain kedua kelas dimana nilai rata-rata KPM matematis pada kelas eksperimen sebesar 0,52 dan pada kelas kontrol sebesar 0,42 . Selain itu terdapat peningkatan rata-rata hasil postes pada kelas yang memperoleh PBM, dimana rata-rata skor tes awal (pretes) sebesar 9,24 naik 
sebesar 33,67 menjadi 42,91. Temuan lain juga menunjukkan bahwa KPM matematis siswa yang pada pembelajarannya menggunakan pendekatan PBM berada pada kualifikasi sedang.

\section{DAFTAR PUSTAKA}

Hendriana, H., \& Sumarmo, U. (2014). Penilaian Pembelajaran matematika. Bandung: Refika Aditama.

Hidayat, W., \& Sariningsih, R. (2018). Kemampuan Pemecahan Masalah Matematis dan Adversity Quotient Siswa SMP Melalui Pembelajaran Open Ended. JNPM (Jurnal Nasional Pendidikan Matematika), 2(1), 109-118.

Muliawati, N. A. (2015). Peningkatan kemampuan Pemecahan Masalah Matematis melalui Pendekatan Problem Based Learning. Universitas Pendidikan Matematika.

Nurlaelasari, F. (2016). Pengaruh Pendekatan problem Based Learning Terhadap Kemampuan Pemecahan Masalah Matematik Siswa MTs di Kota Cimahi. STKIP Siliwangi Bandung.

Pradhini, G. A. (2016). Meningkatkan Kemampuan Komunikasi dan Pemecahan Masalah serta Disposisi Matematis Siswa SMA melalui Strategi REACT. STKIP Siliwangi bandung.

Ruseffendi, E. T. (2010). Penelitian Pendidikan dan Bidang Non-Eksakta Lainnya. Bandung: Tarsito.

Sari, S., Elniati, S., \& Fauzan, A. (2014). Pengaruh Pendekatan Pembelajaran Berbasis Masalah terhadap Kemampuan Pemecahan Masalah Matematika SiswaKelas VIII SMP Negeri 1 Padang Tahun Pelajaran 2013/2014. Jurnal Pendidikan Matematika, 3(2), 5459.

Setiawati, S. (2014). Perbandingan peningkatan Kemampuan Pemecahan Masalah Matematis Siswa SMP antara Yang Memperoleh Pembelajaran Model M-APOS dan Model Problem Based Learning. Universitas Pendidikan Indonesia.

Sumarmo, U. (2013). Berpikir dan Disposisi matematik serta Pembelajarannya. Bandung: Universitas Pendidikan Matematika.

Wahyu, H. (2014). The Implementation of MEAs Instruction to Students' Mathematics Problem Solving and Connecting Ability. In Proceeding of International Conference on Research, Implementation and Education of Mathematics and Sciences 2014. Yogyakarta State University.

Yuniarti, Y. (2016). Pendekatan Pembelajaran Berbasis Masalah Untuk Meningkatkan Pemecahan Masalah Matematis. EDUHUMANIORA:Jurnal Pendidikan Dasar, 2(2).

Zanthy, L. S. (2016). Pengaruh Motivasi Belajar Ditinjau dari Latar Belakang Pilihan Jurusan Terhadap Kemampuan Berpikir Kritis Mahasiswa di Stkip Siliwangi Bandung. Jurnal Teori Dan Riset Matematika ( TEOREMA), 1 .

Zarkasyi, M. W., Lestari, K. E., \& Yudhanegara, M. R. (2015). Penelitian Pendidikan Matematika. Bandung: Refika Aditama. 